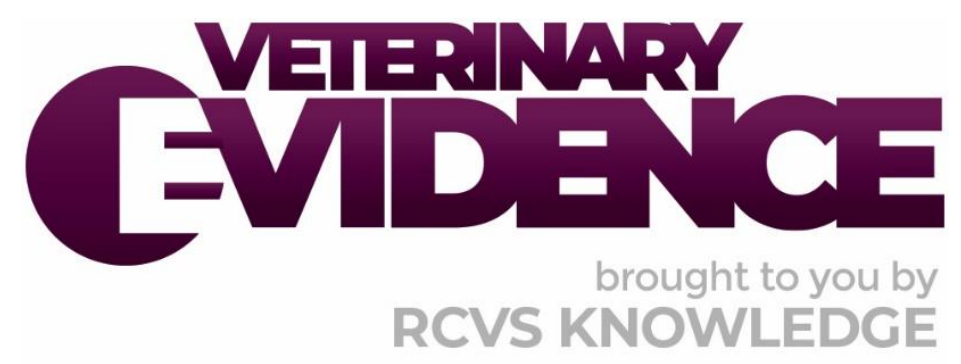

\title{
In dogs with congestive heart failure, is torasemide superior to furosemide as a first line diuretic treatment?
}

\author{
A Knowledge Summary by
}

Leo Packham BVetMed PGDip(VCP) MRCVS ${ }^{*}$

\footnotetext{
${ }^{1}$ University of Bristol, Langford Vets, Langford, Somerset, BS40 5DU

*Corresponding Author (lafpackham@outlook.com)
}

ISSN: 2396-9776

Published: 04 Nov 2020

in: The Veterinary Evidence journal Vol 5, Issue 4

DOI: 10.18849/VE.V5I4.300

Reviewed by: Siddharth Sudunagunta (BVetMed CertAVP(VC) MRCVS) and Kieran Borgeat (BSc BVSc MVetMed CertVC MRCVS DipACVIM DipECVIM-CA

Next Review Date: 20 Feb 2022 


\section{KNOWLEDGE SUMMARY}

\section{PICO question}

In dogs with congestive heart failure, does the use of torasemide as a first line diuretic result in a superior survival time when compared to furosemide?

\section{Clinical bottom line}

\section{Category of research question}

\section{Treatment}

\section{The number and type of study designs reviewed}

Five studies were critically appraised, they were all prospective randomised controlled trials

\section{Strength of evidence}

\section{Moderate}

\section{Outcomes reported}

There is currently a lack of studies looking at comparing furosemide directly with torasemide in patients with congestive heart failure. There are many similarly drawn conclusions from the studies: torasemide is not inferior to furosemide in the treatment of $\mathrm{CHF}$, torasemide is comparable to furosemide at one tenth the dose (or less) and that torasemide may be more effective at diuresis than furosemide with a prolonged duration of action

\section{Conclusion}

There is currently no clear and obvious benefit for the use of torasemide, over furosemide, as a first line diuretic for dogs with congestive heart failure

\section{How to apply this evidence in practice}

The application of evidence into practice should take into account multiple factors, not limited to: individual clinical expertise, patient's circumstances and owners' values, country, location or clinic where you work, the individual case in front of you, the availability of therapies and resources.

Knowledge Summaries are a resource to help reinforce or inform decision-making. They do not override the responsibility or judgement of the practitioner to do what is best for the animal in their care 


\section{Clinical Scenario}

A 6-year-old male neutered Cocker Spaniel presents to you as an emergency, with tachypnoea, dyspnoea, a grade III/VI systolic heart murmur and a recent history of exercise intolerance. After initial stabilisation you have diagnosed stage $C$ degenerative mitral valve disease and plan to start this patient on appropriate oral medication, which will include a diuretic. Typically, furosemide will be used, but is there any evidence to suggest the use of torasemide carries any benefits as a first line diuretic?

\section{The evidence}

A search of the literature revealed five studies relevant to this PICO. Four out of five of these papers had a sample size of 10 or less and the populations were only studied generally for a few weeks. They were all prospective and randomised, though only one study was blinded.

\section{Summary of the evidence}

\begin{tabular}{|c|c|}
\hline Population: & $\begin{array}{l}\text { Dogs } \geq 3 \mathrm{~kg} \text { with congestive heart failure (CHF) due to degenerative } \\
\text { mitral valve disease (DMVD) }\end{array}$ \\
\hline Sample size: & 366 dogs \\
\hline Intervention details: & $\begin{array}{l}\text { Dogs were within one of two groups during each study. Stratum } 1 \\
\text { included dogs that presented with their first CHF episode, needing a } \\
\text { diuretic. Or, dogs that had existing CHF and needing a change in } \\
\text { diuretic dose change due to deterioration. Stratum } 2 \text { included dogs } \\
\text { that had had a previous episode of CHF that were now stable and } \\
\text { without clinical or radiographic signs of CHF. } \\
\text { All dogs received either furosemide ( } n=186 \text { ) or torasemide ( } n= \\
\text { 180) for } 3 \text { months. Doses for furosemide were chosen based on } \\
\text { clinical signs, if a dog was placed into the torasemide the dose of } \\
\text { furosemide was converted to torasemide via a conversion table. } \\
\text { There were two complete studies in this paper, both followed the } \\
\text { above protocol, but the second study changed the conversion } \\
\text { method following safety results, ultimately reducing overall doses of } \\
\text { torasemide. } \\
\text { All dogs were examined by clinicians on day } 0 \text { (inclusion day and } \\
\text { initiation of treatment), } \pm 2 \text { days on days } 7 \text { and } 28 \text {, then } \pm 4 \text { days on } \\
\text { days } 56 \text { and } 84 \text {. At each of these visits dogs received a complete } \\
\text { physical exam, a blood test was performed and radiographs were } \\
\text { obtained of right lateral and dorsoventral projections. }\end{array}$ \\
\hline Study design: & Prospective, multi-centre, multi-national, randomised control trial \\
\hline Outcome studied: & $\begin{array}{l}\text { To demonstrate that torasemide is noninferior to furosemide for } \\
\text { treating dogs with CHF and to compare the two drugs on the time to } \\
\text { reach a composite cardiac end point. } \\
\text { Outcome success of this study was based on the hypothesis that } \\
\text { treatment of Stratum } 1 \text { was expected to improve their clinical } \\
\text { condition and treatment of Stratum } 2 \text { was expected to be able to } \\
\text { maintain their condition. }\end{array}$ \\
\hline
\end{tabular}




\begin{tabular}{|c|c|}
\hline & $\begin{array}{l}\text { Treatment success was based on a composite clinical score which } \\
\text { included assessment of dyspnoea, cough, exercise tolerance and } \\
\text { ascites. CHF was assessed through the radiographic findings and } \\
\text { changes to a patients modified New York Heart Association } \\
\text { classification. } \\
\text { Composite cardiac end point: spontaneous cardiac death, } \\
\text { euthanasia due to heart failure, worsening of CHF class. }\end{array}$ \\
\hline $\begin{array}{l}\text { Main findings: } \\
\text { (relevant to PICO question): }\end{array}$ & $\begin{array}{l}\text { - At the end of Study } 147 / 75 \text { (63\%) of dogs receiving } \\
\text { torasemide had treatment success, over } 42 / 76(55 \%) \text { of dogs } \\
\text { receiving furosemide. At the end of Study } 263 / 105 \text { (60\%) of } \\
\text { dogs receiving torasemide had treatment success, over } \\
65 / 110 \text { (59\%) of dogs receiving furosemide. } \\
\text { - The composite cardiac end point was reached in a shorter } \\
\text { period of time in the furosemide group than the torasemide } \\
\text { group. This was significant. } \\
\text { - Compared to the furosemide group, the torasemide group } \\
\text { had a higher number of adverse effects that were significant. } \\
\text { These included polyuria/polydipsia or urinary incontinence } \\
\text { (as reported by the owner), hepatic enzyme elevation and } \\
\text { renal adverse effects (including elevation in renal } \\
\text { parameters to acute renal failure). }\end{array}$ \\
\hline Limitations: & $\begin{array}{l}\text { - The study was sponsored and monitored by the } \\
\text { manufacturer of an oral torasemide product. } \\
\text { - } 3 \text { months follow-up was a relatively short time frame to } \\
\text { collect data. } \\
\text { There were two baseline variables that were significantly } \\
\text { different between the two treatment groups. These were } \\
\text { duration of heart disease (days) and dyspnoea score. } \\
\text { However, pretrial treatment duration was similar between } \\
\text { the two groups and not significant. } \\
\text { - The composite clinical scoring was semi-objective. }\end{array}$ \\
\hline
\end{tabular}

Peddle et al. (2012)

\begin{tabular}{|r|l|}
\hline Population: & Dogs with stable CHF due to DMVD \\
\hline Sample size: & Seven dogs \\
\hline Intervention details: & $\begin{array}{l}\text { All dogs enrolled in the study had already been receiving furosemide } \\
\text { orally, twice daily, for the preceding 14 days. (Other medication was } \\
\text { permitted, though could not have had a dose adjustment within the } \\
\text { preceding 7 days). At day 0 (enrollment), dogs were randomly } \\
\text { assigned into two groups: either continue existing furosemide dose } \\
\text { (n=4) or to change to torasemide at an equivalent dose ( } \mathrm{n}=3 \text { ). } \\
\text { (Equivalent dosing was calculated at one tenth that of their initial } \\
\text { furosemide dose). }\end{array}$ \\
& $\begin{array}{l}\text { On day 7 there was crossover of the two groups. And on day } 14 \text { the } \\
\text { study ended. Therefore, each patient received 7 days of each } \\
\text { therapy. At days 0, 7 and 14 there was evaluation of each variable }\end{array}$ \\
\hline
\end{tabular}




\begin{tabular}{|c|c|}
\hline & $\begin{array}{l}\text { (clinical, laboratory, radiographic and quality of life). Each dog was } \\
\text { evaluated by the same clinician on all three visits. }\end{array}$ \\
\hline Study design: & Prospective, double-blinded, randomised, crossover study \\
\hline Outcome studied: & $\begin{array}{l}\text { In both groups the variables that were assessed were: } \\
\text { - } \text { Clinical variables: body weight, resting heart rate and } \\
\text { respiratory rate. } \\
\text { Laboratory variables: non-invasive systolic blood pressure, } \\
\text { urine specific gravity, blood urea nitrogen (BUN), creatinine, } \\
\text { BUN/creatinine ratio, phosphorus, calcium, sodium, } \\
\text { potassium, chloride, carbon dioxide, albumin and anion gap. } \\
\text { - Radiographic variables: A right lateral and ventrodorsal } \\
\text { thoracic radiograph, evaluated by a board-certified } \\
\text { cardiologist blinded to the patient's treatment. Vertebral } \\
\text { heart size (VHS) was used to assess heart size. } \\
\text { Quality of life variables: As perceived by the owner, quality } \\
\text { of life (QoL) was assessed via a 'Functional Evaluation of } \\
\text { Cardiac Health' questionnaire (Freeman, et al., 2005). The } \\
\text { owners were also asked to subjectively record any clinical } \\
\text { side effects or changes in condition of their pet, though } \\
\text { these were not included in the table of results. }\end{array}$ \\
\hline $\begin{array}{l}\text { Main findings: } \\
\text { (relevant to PICO question): }\end{array}$ & $\begin{array}{l}\text { - Out of the entire study population, no dog in either group } \\
\text { developed CHF either clinically or radiographically at any } \\
\text { time. } \\
\text { - There were increases in creatinine, BUN, phosphorus, } \\
\text { carbon dioxide, albumin and anion gap following the } \\
\text { torasemide treatment that were all significant. } \\
\text { - There were decreases in urine specific gravity (USG) and } \\
\text { chloride following the torasemide treatment that were both } \\
\text { significant. } \\
\text { - There was no significance difference in clinical, radiographic } \\
\text { or QoL score variables between the two therapies. } \\
\text { With regards to the subjective reports by the owners; there } \\
\text { were three. Two of which stated that the dogs urinated } \\
\text { more frequently during torasemide therapy and one of } \\
\text { which stated that the dog urinated less frequently during } \\
\text { the furosemide therapy. }\end{array}$ \\
\hline Limitations: & $\begin{array}{l}\text { - Small study sample size. Only seven dogs were used in total. } \\
\text { - Although using an evaluated and known questionnaire to } \\
\text { assess patient QoL, the assessment by owners carries an } \\
\text { element of subjectivity with it. } \\
\text { - } \quad \text { All dogs within the study were clinically stable and had } \\
\text { received furosemide for at least } 14 \text { days prior to enrollment. } \\
\text { - The study was over such a short time period that it is } \\
\text { extremely difficult to forecast any long-term benefits of one } \\
\text { therapy over the other. } \\
\text { Visits to the vet did occur at different times of the day } \\
\text { between patients. Due to the pharmacodynamic nature of } \\
\text { diuretics, this may affect the significance of some variables } \\
\text { (for example time between tablet given and urine specific } \\
\text { gravity). The authors do note this and advise that each }\end{array}$ \\
\hline
\end{tabular}


individual dog was assessed at the same time for each of their three visits.

- Lack of a washout period between therapies.

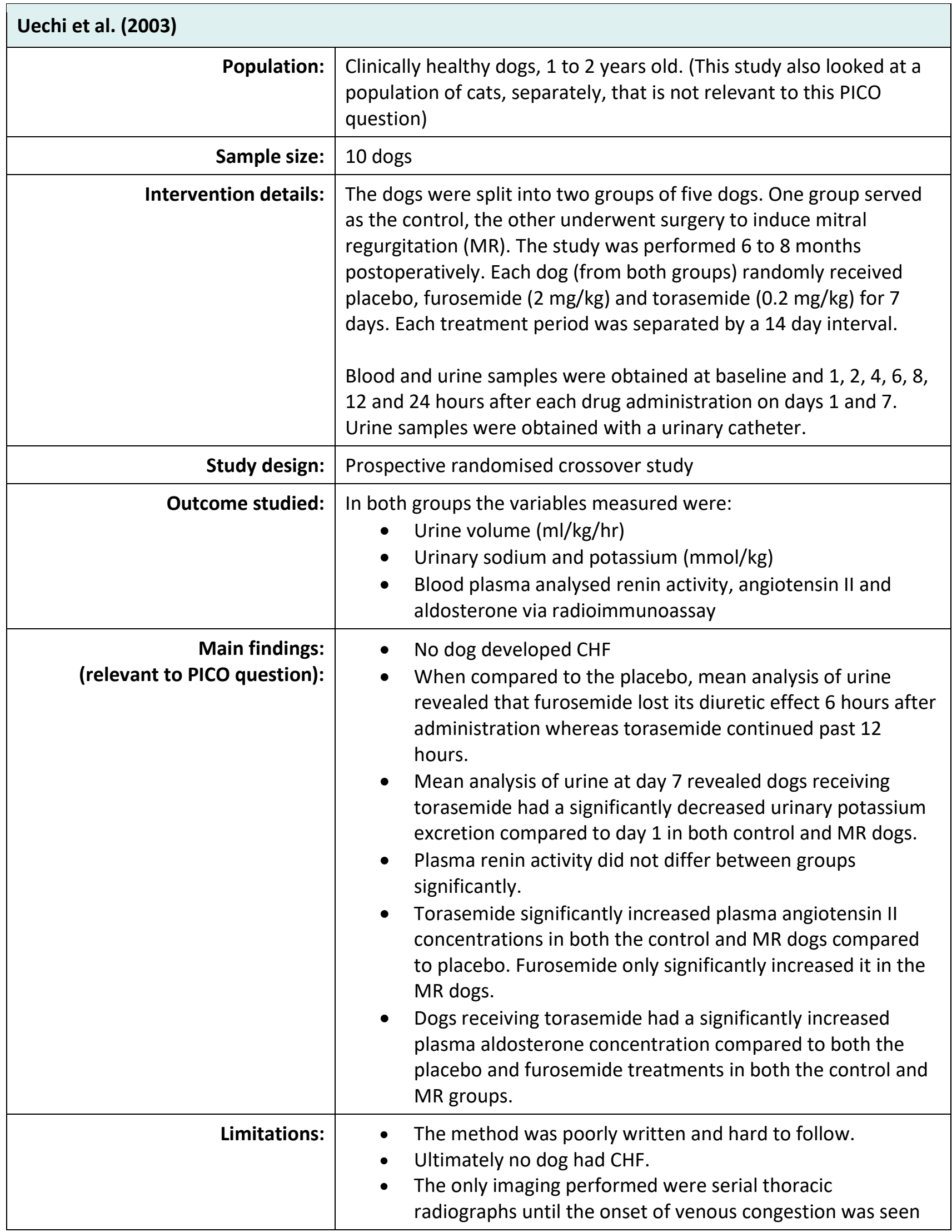




\begin{tabular}{|l|l|}
\hline & $\begin{array}{l}\text { and a single echocardiogram } 1 \text { month postoperatively. The } \\
\text { description of surgery is not clear between the cat and dog } \\
\text { population. }\end{array}$ \\
The MR was surgically induced, the changes to the \\
cardiovascular system may not be representative of \\
acquired mitral valve regurgitation.
\end{tabular}

\begin{tabular}{|c|c|}
\hline \multicolumn{2}{|l|}{ Hori et al. (2007) } \\
\hline Population: & Healthy dogs between 2 and 8 -years-old \\
\hline Sample size: & Eight dogs \\
\hline Intervention details: & $\begin{array}{l}\text { Dogs were randomised to receive either placebo, furosemide ( } 2 \\
\mathrm{mg} / \mathrm{kg} \text { ) or torasemide }(0.2 \mathrm{mg} / \mathrm{kg}) \text {, orally twice daily, for } 14 \text { days. } \\
\text { Each dog received all three treatments for } 14 \text { days, with at least a } 7 \\
\text { day interval between treatments. } \\
\text { Indwelling urinary catheters were placed in all dogs. Baseline } \\
\text { (pretreatment) data was obtained through blood and urine samples } \\
\text { collected following complete urination on the first of each } 14 \text { day } \\
\text { cycle. } \\
\text { Blood and urine samples were collected on day } 1 \text { and } 14 \text { at } 1,2,4,6 \text {, } \\
8,12 \text { and } 24 \text { hours after diuretic or placebo administration. Day } 1 \\
\text { and day } 14 \text { gave short- and long-term results respectively. }\end{array}$ \\
\hline Study design: & Prospective randomised crossover study \\
\hline Outcome studied: & $\begin{array}{l}\text { In all three groups there were two main groups of variables } \\
\text { measured: } \\
\text { - Urine - urine volume (ml/kg/hr), urine specific gravity and } \\
\text { urine creatinine concentration were measured. } \\
\text { - Blood - haematocrit, plasma protein (via refractometry), } \\
\text { electrolytes (sodium, potassium and chloride), plasma BUN, } \\
\text { creatinine and aldosterone were measured. } \\
\text { - Body weight was also recorded. }\end{array}$ \\
\hline $\begin{array}{l}\text { Main findings: } \\
\text { (relevant to PICO question): }\end{array}$ & $\begin{array}{l}\text { The author's use of short- and long-term is to mean } 1 \text { and } 14 \text { days } \\
\text { respectively. } \\
\text { The following statements apply to all dogs: } \\
\text { - Short-term administration of furosemide and torasemide } \\
\text { significantly increased urine volume both compared to } \\
\text { baseline (pretreatment) and placebo. } \\
\text { - Long-term administration of both furosemide and } \\
\text { torasemide decreased urine specific gravity significantly. } \\
\text { - Compared to placebo, long-term administration of } \\
\text { torasemide significantly increased urine volume. This was } \\
\text { not the case with furosemide. } \\
\text { - With respect to furosemide, short- and long-term } \\
\text { administrations of torasemide increased urine volume, } \\
\text { which was significant. } \\
\text { Both furosemide and torasemide treatments significantly } \\
\text { increased BUN and plasma creatinine, after long-term } \\
\text { administration compared to baseline. }\end{array}$ \\
\hline
\end{tabular}




\begin{tabular}{|l|l|}
\hline - & $\begin{array}{l}\text { Long-term administration of furosemide and torasemide } \\
\text { significantly increased plasma aldosterone concentrations } \\
\text { compared to baseline. It was significantly higher with } \\
\text { torasemide compared to furosemide. }\end{array}$ \\
\hline Limitations: & $\begin{array}{l}\text { Small population size of only eight dogs, all of which were } \\
\text { clinically healthy. Therefore, assumptions made about the } \\
\text { use of these diuretics and their actions in canine patients } \\
\text { with cardiovascular disease may not be representative, } \\
\text { especially for their use in the treatment of CHF, their main } \\
\text { indication for use. The authors do highlight this limitation in } \\
\text { their discussion. } \\
\text { The study quotes 'long-term' usage as } 14 \text { days. Although the } \\
\text { study demonstrated that there were significant differences } \\
\text { found in variables between day } 1 \text { and day } 14, \text { in a clinical } \\
\text { setting there is likely to be a much longer period spent on } \\
\text { diuretics. Especially in those patients with stable CHF, such } \\
\text { as the DMVD patients. } \\
\text { The authors state that a relatively high dose of torasemide } \\
\text { was used to exacerbate the therapeutic effects, } \\
\text { demonstrating beneficial effects over furosemide in the } \\
\text { study. This may not be present at lower doses, used more } \\
\text { commonly in the clinical setting. } \\
\text { The interval between groups was not specified, only stated } \\
\text { as 'at least } 7 \text { days'. It is unknown whether some dogs may } \\
\text { have had a longer wash-out period than others. }\end{array}$ \\
\hline
\end{tabular}

Potter et al. (2019)

\begin{tabular}{|r|l|}
\hline Population: & Healthy, middle-aged, purpose-bred laboratory Beagles \\
\hline Sample size: & Six dogs \\
\hline Intervention details: & $\begin{array}{l}\text { There were three treatments within the study: placebo, furosemide } \\
(2 \mathrm{mg} / \mathrm{kg}) \text { and torasemide }(0.1 \mathrm{mg} / \mathrm{kg}) \text {. All three treatments were } \\
\text { given per os (PO), every } 12 \text { hours (q12), for } 10 \text { days and between } \\
\text { each treatment there was a } 10 \text { day washout period. Each dog was } \\
\text { randomly placed into a treatment group and there were only two } \\
\text { dogs on the same treatment at any one time. All dogs ultimately } \\
\text { received all three treatments over the course of the study. } \\
\text { Day }-1 \text { was the day before each } 10 \text { day period started (there was no } \\
\text { day } 0 \text { ) and on this day blood work, urinalysis and clinical parameters } \\
\text { were recorded. It was used to reference 'pretreatment' data. } \\
\text { Blood was taken on days }-1,1,5 \text { and } 9 \text {. Urine was collected on days } \\
-1,2,6 \text { and } 10 . \text { Water consumption was measured during the study } \\
\text { in ml/kg/day. } \\
\text { Prior to urinary catheterisation the dogs were sedated. }\end{array}$ \\
\hline Study design: & Prospective randomised crossover study \\
\hline Outcome studied: & $\begin{array}{l}\text { To compare the magnitude of renin-angiotensin-aldosterone } \\
\text { system (RAAS) activation between furosemide and torasemide. The }\end{array}$ \\
\hline
\end{tabular}




\begin{tabular}{|c|c|}
\hline & $\begin{array}{l}\text { authors hypothesised that the effect would be comparable. They } \\
\text { also indirectly evaluated a purported anti-aldosterone effect of } \\
\text { torasemide. } \\
\text { During each treatment period multiple variables were recorded: } \\
\text { - Clinical parameters (blood pressure, body weight and heart } \\
\text { rate) } \\
\text { Blood (BUN, creatinine, potassium, sodium, chloride, } \\
\text { multiple angiotensin peptides (via liquid chromatography- } \\
\text { tandem mass spectrometry) and aldosterone) } \\
\text { Urine (USG), creatinine, potassium, sodium, chloride, 24hr } \\
\text { urine volume and aldosterone. Electrolyte free water } \\
\text { clearance }\end{array}$ \\
\hline $\begin{array}{l}\text { Main findings: } \\
\text { (relevant to PICO question): }\end{array}$ & $\begin{array}{l}\text { The following statements apply to all dogs (unless where an average } \\
\text { is indicated: } \\
\text { - Throughout the study there was no significant differences } \\
\text { within, or between, treatment groups for BUN, sodium or } \\
\text { potassium (as well as blood pressure, body weight and heart } \\
\text { rate). } \\
\text { - Hypochloraemia was present in both diuretic treatment } \\
\text { groups when compared to placebo, and average serum } \\
\text { chloride concentrations were lower in the torasemide group } \\
\text { compared to the furosemide group. These were all } \\
\text { statistically significant findings. } \\
\text { - Average serum creatinine was significantly greater than } \\
\text { placebo in both diuretic treatment groups. Though it } \\
\text { remained within reference range in all treatment groups. } \\
\text { - } 24 \text { hour urine volume was greater in both diuretic groups } \\
\text { when compared to placebo. On day 10, the } 24 \text { hour urinary } \\
\text { output of the torasemide group was significantly greater } \\
\text { than that of the furosemide group. } \\
\text { Urinary excretion of potassium was not significantly } \\
\text { different between treatment groups. } \\
\text { Regarding the RAAS values measured; there was no } \\
\text { significant difference between diuretics. Suggesting they } \\
\text { achieved a similar level of RAAS activation, and torasemide } \\
\text { was considered 'equipotent' at approximately one-twentieth } \\
\text { the dose of furosemide. }\end{array}$ \\
\hline Limitations: & $\begin{array}{l}\text { - The study was funded by the manufacturer of an oral } \\
\text { torasemide product. } \\
\text { - Small study sample size of only six dogs. } \\
\text { - The population of dogs used in this study is not } \\
\text { representative of those cases seen in clinic. The authors } \\
\text { highlight this and state that because the subjects were } \\
\text { 'normal' dogs, it does not replicate the derangements seen } \\
\text { in heart failure. This is particularly true of RAAS activation } \\
\text { during naturally occurring CHF. } \\
\text { - The administration of treatment in the study does not mimic } \\
\text { CHF; the subjects only received treatment for } 10 \text { days (of } \\
\text { any one product) which is not typically representative of the } \\
\text { length of time animals are treated for CHF. }\end{array}$ \\
\hline
\end{tabular}




\begin{tabular}{|l|l|}
\hline - & $\begin{array}{l}\text { Although the authors state that the risk of sequence effect } \\
\text { would have been minimised by the } 10 \text { day washout period, } \\
\text { there may still be some element of unevaluated sequence } \\
\text { effect present. }\end{array}$ \\
\hline
\end{tabular}

\section{Appraisal, application and reflection}

There were some case reports published within the literature that looked specifically at torasemide being used on canine patients with cardiovascular disease. These were excluded from the search results as not only were they a poorer quality evidence base, but they were not comparing furosemide and torasemide. Of the five papers examined, following the literature search, only one paper (Chetboul et al., 2017) had a reasonable population number; 366, the other four papers had only 10 dogs or less. Even though all papers that were used for this Knowledge Summary were prospective, it may be preferable to have a large retrospective study comparing the use of torasemide and furosemide with much greater sample size.

Congestive heart failure due to degenerative mitral valve disease is typically a chronic disease that is managed over a far longer period than these studies sustained therapy for. Chetboul et al. (2017) had a superior treatment time ( 3 months) compared to the other four papers studied; none of which had a treatment time greater than 14 days on either furosemide or torasemide. This detracts from the ability to relate these findings into real cases seen within the clinic.

There are many similarly drawn conclusions from the above studies: torasemide is noninferior to furosemide in the treatment of $\mathrm{CHF}$, torasemide is comparable to furosemide at one tenth the dose (or less) and that torasemide may be more effective at diuresis than furosemide with a prolonged duration of action. Within human medicine there are studies demonstrating that, compared to furosemide, torasemide can reduce morbidity and mortality associated with CHF failure (Cosín \& Díez, 2002). Torasemide is often used as a rescue diuretic therapy (Oyama et al., 2011). Given some of the frequently suggested positive findings of torasemide in the above studies, such as reduced diuretic resistance, reduced cardiac remodelling and a potassium sparing nature new studies into the long-term safety of torasemide may be rewarding for the treatment of animals in chronic CHF. In view of the strength of evidence and the outcomes from the studies, no clear and obvious benefit to the use of torasemide, over furosemide, as a first line diuretic for dogs with congestive heart failure can be drawn. 


\section{Methodology Section}

\begin{tabular}{|c|c|}
\hline \multicolumn{2}{|l|}{ Search Strategy } \\
\hline $\begin{array}{r}\text { Databases searched and dates } \\
\text { covered: }\end{array}$ & $\begin{array}{l}\text { CAB Abstracts on OVID Platform (1973 - } 2020 \text { Week 06) } \\
\text { Medline on OVID Platform (1946 - February 2020) } \\
\text { Web of Science ( } 1900 \text { - February 2020) }\end{array}$ \\
\hline Search terms: & $\begin{array}{l}\text { CAB Abstracts and Medline: } \\
\text { 1. } \text { Exp dogs/ } \\
\text { 2. (Dog OR dogs OR canin* OR canid*).mp } \\
\text { 3. (Torasemide OR torsemide OR upcard).mp } \\
\text { 4. Furosemide/ } \\
\text { 5. (Furosemide OR frusemide).mp } \\
\text { 6. (1 OR 2) AND } 3 \text { AND (4 OR 5) } \\
\text { Web of Science: } \\
\text { 1. Dogs OR dog OR canin* OR canid* } \\
\text { 2. Torasemide OR torsemide OR upcard } \\
\text { 3. Furosemide OR frusemide } \\
\text { 4. } 1 \text { AND } 2 \text { AND } 3\end{array}$ \\
\hline Dates searches performed: & 20 Feb 2020 \\
\hline
\end{tabular}

Exclusion / Inclusion Criteria

Exclusion: Conference proceedings, opinions, letters, case reports, articles not in English (or English translations unable to be located) and those articles not relevant to the PICO or involving the wrong species.

Inclusion: All appropriate articles relevant to the PICO. 


\begin{tabular}{|c|c|c|c|c|c|}
\hline \multicolumn{6}{|c|}{ Search Outcome } \\
\hline Database & $\begin{array}{c}\text { Number of } \\
\text { results }\end{array}$ & $\begin{array}{l}\text { Excluded - } \\
\text { English version } \\
\text { unavailable }\end{array}$ & $\begin{array}{l}\text { Excluded - } \\
\text { Not relevant } \\
\text { to PICO } \\
\text { question }\end{array}$ & $\begin{array}{c}\text { Excluded - } \\
\text { Conference } \\
\text { proceedings, } \\
\text { opinion, letter or } \\
\text { case reports }\end{array}$ & $\begin{array}{c}\text { Total relevant } \\
\text { papers }\end{array}$ \\
\hline $\begin{array}{l}\mathrm{CAB} \\
\text { Abstracts }\end{array}$ & 21 & 10 & 0 & 6 & 5 \\
\hline Medline & 15 & 0 & 9 & 1 & 5 \\
\hline $\begin{array}{l}\text { Web of } \\
\text { Science }\end{array}$ & 27 & 0 & 22 & 1 & 4 \\
\hline \multicolumn{5}{|c|}{ Total relevant papers when duplicates removed } & 5 \\
\hline
\end{tabular}

\section{CONFLICT OF INTEREST}

The author declares no conflicts of interest. The author would like to thank the University of Bristol, Veterinary Science library services.

\section{REFERENCES}

1. Chetboul, V., Pouchelon, J.L., Menard, J., Blanc, J., Desquilbet, L., Petit, A., Rougier, S., Lucats, L., and Woehrle, F. (2017). Short-Term Efficacy and Safety of Torasemide and Furosemide in 366 Dogs with Degenerative Mitral Valve Disease: The TEST Study. Journal of Veterinary Internal Medicine, 31(6): 1629-1642. DOI: https://doi.org/10.1111/jvim.14841

2. Cosín, J. \& Díez, J. TORIC investigators (2002) Torasemide in chronic heart failure: results of the TORIC study. European Journal of Heart Failure, 4(4): 507-13.

3. Freeman, L. M., Rush, J. E., Farabaugh, A. E. \& Must, A. (2005). Development and evaluation of a questionnaire for assessing health-related quality of life in dogs with cardiac disease. Journal of the American Veterinary Medical Association, 226(11), 1864-1868.

DOI: https://doi.org/10.2460/javma.2005.226.1864

4. Hori, Y., Takusagawa, F., Ikadai, H., Uechi, M., Hoshi, F., and Higuchi, S. (2007). Effects of oral administration of furosemide and torsemide in healthy dogs. American Journal of Veterinary Research, 68(10): 1058-1063. DOI: https://doi.org/10.2460/ajvr.68.10.1058

5. Oyama, M.A., Peddle, G.D., Reynolds, C.A., and Singletary, G.E. (2011). Use of the loop diuretic torsemide in three dogs with advanced heart failure. Journal of Veterinary Cardiology, 13(4): 287-292. DOI: https://doi.org/10.1016/i.jvc.2011.10.001

6. Peddle, G.D., Singletary, G.E., Reynolds, C.A., Trafny, D.J., MacHen, M.C., and Oyama, M.A. (2012). Effect of torsemide and furosemide on clinical, laboratory, radiographic and quality of life variables in 
dogs with heart failure secondary to mitral valve disease. Journal of Veterinary Cardiology, 14(1): 253259. DOI: https://doi.org/10.1016/j.jvc.2012.01.003

7. Potter, B.M., Ames, M.K., Hess, A., and Poglitsch, M. (2019). Comparison between the effects of torsemide and furosemide on the renin-angiotensin-aldosterone system of normal dogs. Journal of Veterinary Cardiology, 26: 51-62. DOI: https://doi.org/10.1016/i.jvc.2019.11.003

8. Uechi, M., Matsuoka, M., Kuwajima, E., Kaneko, T., Yamashita, K., Fukushima, U., and Ishikawa, Y. (2003). The effects of the loop diuretics furosemide and torasemide on diuresis on dogs and cats. Journal of Veterinary Medical Science, 65(10): 1057-1061.

DOI: https://doi.org/10.1292/ivms.65.1057 


\section{EVIIDEFeE

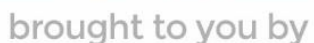 \\ RCVS KNOWLEDGE}

\section{Intellectual Property Rights}

Authors of Knowledge Summaries submitted to RCVS Knowledge for publication will retain copyright in their work, and will be required to grant RCVS Knowledge a non-exclusive license of the rights of copyright in the materials including but not limited to the right to publish, re-

publish, transmit, sell, distribute and otherwise use the materials in all languages and all media throughout the world, and to license or permit others to do so.

\section{Disclaimer}

Knowledge Summaries are a peer-reviewed article type which aims to answer a clinical question based on the best available current evidence. It does not override the responsibility

of the practitioner. Informed decisions should be made by considering such factors as individual clinical expertise and judgement along with patient's circumstances and owners' values. Knowledge Summaries are a resource to help inform and any opinions expressed within the Knowledge Summaries are the author's own and do not necessarily reflect the view of the RCVS Knowledge. Authors are responsible for the accuracy of the content. While the

Editor and Publisher believe that all content herein are in accord with current recommendations and practice at the time of publication, they accept no legal responsibility

for any errors or omissions, and make no warranty, express or implied, with respect to material contained within.

For further information please refer to our Terms of Use.

RCVS Knowledge is the independent charity associated with the Royal College of Veterinary Surgeons (RCVS). Our ambition is to become a global intermediary for evidence based veterinary knowledge by providing access to information

that is of immediate value to practicing veterinary professionals and directly contributes to evidence based clinical decision-making.

https://www.veterinaryevidence.org/

RCVS Knowledge is a registered Charity No. 230886.

Registered as a Company limited by guarantee in England and Wales No. 598443.

Registered Office: Belgravia House, 62-64 Horseferry Road, London SW1P 2AF

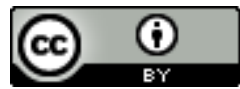

This work is licensed under a Creative Commons Attribution 4.0 International License 